\title{
Pengembangan Lembar Kerja Siswa (LKS) Saintifik Berbasis \\ Keterampilan Berpikir Kritis untuk \\ Siswa Kelas V SD/MI di Kabupaten Jombang
}

\author{
Indra Kusuma Wardani ${ }^{1}$, Galuh Tisna Widiana ${ }^{2}$ \\ Universitas Pesantren Tinggi Darul 'Ulum \\ indrakusumawardani@mipa.unipdu.ac.id
}

\begin{abstract}
Abstrak
Penelitian ini bertujuan untuk mengembangkan Lembar Kerja Siswa (LKS) saintifik berdasarkan indikator keterampilan berpikir kritis. LKS dikembangkan menggunakan model 4D, yang direduksi menjadi 3D, dengan desain penelitian one group pre-test post-test design. Kegiatan penelitian diimplementasikandalamdua kali replikasi padapembelajaran IPA di kelas V SD Negeri Brodot I, Kabupaten Jombang. Hasil penelitian menunjukkan LKS memenuhi kriteria validitas dan ke-efektifan. Tingkat reliabilitas dan validitas LKS masing-masing menunjukkan rata-rata persentase $86,35 \%$ dan $92,64 \%$. Kriteria saintifik menunjukkan peningkatan n-gain lebih dari 0,70 pada indikator menanya dan menanggapi pertanyaan, sedangkan nilai n-gain berkriteria tinggi untuk keterampilan berpikir kritis ditunjukkan oleh indikator analisis dan perumusan variabel percobaan. Keterbacaan LKS diukur menggunakan uji rumpang (cloze procedure) yang menunjukkan persentase 95,38\%. Pada penelitian ini aktivitas siswa dominan pada kegiatan mengerjakan LKS dan melakukan percobaan ilmiah. Berdasarkan temuan-temuan penelitian dapat disimpulkan bahwa LKS yang dikembangkan layak untuk melatihkan kemampuan saintifik dan keterampilan berpikir kritis.
\end{abstract}

Kata Kunci : LKS; saintifik; keterampilan berpikir kritis

Abstract

This research aims to develop Student Worksheet (LKS) scientifically based on indicators of critical thinking skills. LKS was developed using a 4D model, which is reduced to $3 D$, with a one-group pre-test post-test design design. The research activity is implemented in two replication on science lesson in Grade V of SD Negeri Brodot I, Jombang Regency. The results show that LKS meet the criteria of validity and effectiveness. The level of reliability and validity of $L K S$ respectively shows the average percentage of $86.35 \%$ and $92.64 \%$. The scientific criterion shows an increase of n-gain over 0.70 in the indicator of questioning and responding to the question, while the high$n$-gain value for critical thinking is indicated by the analysis indicator and the formulation of experimental variables. LKS legibility was measured using a cloze test indicating a $95.38 \%$ percentage. In this study the student activity is dominant in the activities of doing the LKS and conducting scientific experiments. Based on the findings of the study it can be concluded that the developed LKS is feasible to trained scientific ability and critical thinking skills.

Keywords : Student Worksheet (LKS); scientific; critical thinking skills 


\section{PENDAHULUAN}

IPA tidak dapat dilepaskan dari karakteristik ilmiah atau saintifik. Saintifik dalam pembelajaran sebagaimana dimaksud meliputi mengamati, menanya, menalar, mencoba, membentuk jejaring untuk semua mata pelajaran.Salah satu faktor yang menentukan keberhasilan implementasi pembelajaran IPA adalah kualitas guru dalam mengembangkan pengalamannya, membuat perencanaan pembelajaran yang sesuai kurikulum, serta menguasai materi pembelajaran. Selain itu, pembelajaran lebih dipusatkan pada siswa dengan melibatkan siswa dalam kegiatan pembelajaran dan mengajak siswa untuk berfikir kritis akan memberikan kebermaknaan suatu pembelajaran sehingga pembelajaran tidak hanya pada lingkup teori saja namun dikaitkan dengan permasalahan dan pemecahanya. Pengembangan LKS berbasis saintifik untuk melatihkan ketrampilan berfikir kritis memberikan gambaran tentang suatu bahan ajar yang tidak hanya menekankan pada tahapan saintifik namun juga melatihkan ketrampilan berfikir kritis siswa sehingga pembelajaran tidak hanya lingkup teori saja namun dikaitkan dengan permasalahan dan pemecahanya.

Tujuan khusus dari penelitian ini untuk mendeskripsikan keterbacaan LKS berbasis saintifik, mengetahui keefektifan LKS berbasis saintifik serta melatihkan ketrampilan berfikir kritis siswa melalui LKS berbasis saintifik. Tujuan Jangka panjang pengembanga LKS berbasis saintifik untuk melatihkan ketrampilan berfikir kritis tidak hanya pada mata pelajaran ipa namun diharapkan dapat dikembangkan pada mata pelajaran lain. Untuk mencapai tujuan tersebut penelitian pengembangan LKS berbasis saintifik untuk melatihkan ketrampilan berfikir kritis siswa kelas V SDN Brodot I menggunakan metode penelitian research and development (R\&D) yang terdiri dari tiga tahap penelitian yaitu studi pendahuluan, pengembangan dan pengujian. Penelitian ini menggunakan model pengembangan 4D yang terdiri atas tahap define, design, develop dan disseminate.

Kegiatan pembelajaran IPA pada tingkat pendidikan dasar, SD atau MI, tidak dapat terlepas dari karakteristik ilmiah yang didasarkan pada pendekatan saintifik. Pendekatan saintifik pada pembelajaran IPA mengajarkan siswa untuk memahami teori atau konsep IPA melalui aktivitasilmiah yang meliputi kegiatan mengamati, menanya, menalar, mencoba dan membuat jejaring dengan pengetahuan lainnya(Kemendikbud, 2013). Aktivitas-aktivitas ilmiah tersebut menjadikan pembelajaran IPA tidak hanya menitikberatkan pada kemampuan kognitif siswa tetapi juga mengembangkan nilai dan sikap ilmiah. Nilai dan sikap ilmiah yang ditanamkan kepada siswa sejak tingkat pendidikan dasar dapat menjadi dasar tercapainya tujuan pembelajaran IPA dengan menjadikan kegiatan pembelajaran lebih aktif mengkonstruksi pengetahuan berdasarkan informasi dan fakta yang ditemukan siswa dari berbagai sumber (Sani, 2014).Pengkonstruksian informasi dan fakta dari berbagai sumber ini dimaksudkan untuk memberikan pemahaman kepada siswa bahwa penguasaan konsep IPA tidak hanya didapatkan dari penyampaian materi pelajaran oleh guru atau kegiatan 
pembelajaran di kelas tetapi dapat juga diperoleh melalui aktivitas ilmiah berdasarkan pada bukti-bukti empiris yangbersifat operasional (Hosnan, 2014).

Pendekatan saintifik mengajarkan siswa untuk berperan sebagai seorang ilmuwan yang berpikir secara sistematis, logis dan kritis dalam upaya memecahkan suatu masalah menggunakan metode ilmiah tertentu. Metode ilmiah berbeda dari metode pemecahan masalah yang umumnya digunakan pada kegiatan pembelajaran tradisional. Harrel (2010:159), mengemukakan salah satu faktor yang menentukan keberhasilan implementasi pembelajaran IPA adalah kualitas guru dalam mengembangkan pengalamannya, membuat perencanaan pembelajaran yang sesuai kurikulum, serta menguasai materi pembelajaran. Selain itu, pembelajaran lebih dipusatkan pada siswa dengan melibatkan siswa dalam kegiatan pembelajaran dan mengajak siswa untuk berfikir kritis akan memberikan kebermaknaan suatu pembelajaran sehingga pembelajaran tidak hanya pada lingkup teori saja namun dikaitkan dengan permasalahan dan pemecahanya.

Keberadaan bahan ajar dalam pembelajaran sangat membantu dalam proses belajar mengajar menurut Smaldino, et al (2007:8) mengatakan bahan ajar merupakan perangkat khusus yang digunakan dalam pembelajaran yang dapat mempengaruhi belajar. Bahan ajar juga memiliki manfaat baik bagi siswa maupun bagi guru pernyataan tersebut dapat dibuktikan dari hasil penelitian (Erawati, 2013; Rahmawati, 2013), yakni:; bahan ajar IPA kontekstual mampu meningkatkan prestasi belajar siswa kelas VIII olahraga SMPN 1 Batu; dan bahan ajar IPA berbasis aktivitas mampu meningkatkan kemampuan berpikir kritis dan karakter siswa kelas VI semester I SDN Ngoro 2 Jombang.

LKS atau Lembar Kegiatan Siswa (student worksheet) atau Lembar Kerja Siswa merupakan salah satu jenis dari bahan ajar. LKS merupakan lembaran-lembaran berisi tugas yang harus dikerjakan oleh peserta didik. Lembar kegiatan biasanya berupa petunjuk, langkah-langkah untuk menyelesaikan suatu tugas (Depdiknas, 2008;13) Dapat dikatakan LKS merupakan bahan ajar berbasis aktifitas yang berpusat pada siswa yang dikemas dalam bentuk bentuk lembaran kegiatan. Dalam dunia pendidikan keberadaan LKS sangat memberikan kontribusi positif dalam pembelajaran. Namun kenyataanya LKS yang beredar saat ini berisikan kumpulan soal dan rangkuman materi yang harus dikerjakan siswa dan di kelas ataupun sebagai PR. JIka berisi kumpulan soal maka disebut lembar penilaian, seharusnya LKS berupa langkah kerja yang berbasis aktifitas siswa untuk menyelesaikan suatu tugas. Kenyataan lain LKS saat ini tidak memperhatikan karakteristik anak SD/MI di lihat dari tampilan dari layout LKS. LKS dengan fullteks yang hurufnya terlalu kecil, berwarna hitam putih dan sedikit gambar ataupun tidak ada gambar dalam 1 halaman. Ini menunjukkan bahwa LKS tersebut dari segi tampilan kurang menarik dan kurang sesuai dengan karekteristik anak yang suka dengan warna yang mencolok dan gambar.

Solusi pemecahan masalah di atas dapat dilakukan dua alternative untuk terlaksananya pembelajaran agar tercapai tujuan sesuai dengan yang diinginkan, yaitu;pertama pengembangan bahan ajar yang sesuai dengan teoritis, sesuai dengan 
karakteristik siswa kedua Mendekatkan pembelajaran IPA pada pendekatan saintifik dan melatihkan ketrampilan berfikir kritis siswa. Alasan peneliti mengangkat permasalahan tersebut sebagai objek penelitian dengan judul Pengembangan Lembar Kerja Siswa (LKS) Berbasis Saintifik untuk Melatihkan Keterampilan Berpikir Kritis untuk Siswa Kelas V SDN Brodot I di Kabupaten Jombang. karena peneliti ingin mengetahui sejauh mana keterbacaan dan keefektifan Lembar Kerja Siswa (LKS) Berbasis Saintifik yang diterapkan dalam kegiatan pembelajaran serta bagaimana melatihkan ketrampilan berfikir kritis siswa dengan menggunakan Lembar Kerja Siswa (LKS) Berbasis Saintifik.

\section{METODE PENELITIAN}

Pada penelitian pengembangan Lembar Kerja Siswa (LKS) saintifik berbasis keterampilan berpikir kritis untuk siswa kelas V SDN Brodot I di Kabupaten Jombang I untuk didasarkan pada metode penelitian Research And Development (R\&D). Metode penelitian ini digunakan untuk menghasilkan produk tertentu dan menguji keefektifan produk tersebut (Sugiyono, 2009). Pada bidang pendidikan, metode R\&D diarahkan untuk mengembangkan dan menguji bahan ajar (Sukmadinata, 2005). Metode R\&D dalam penelitian ini terdiri atas tiga tahap penelitian (Borg, 2001), yaitu studi pendahuluan, pengembangan LKS saintifik berbasis berfikir kritis dan pengujian LKS saintifik berbasis berfikir kritis.

Subyek penelitian adalah siswa kelas V SD Negeri Brodot I, Kabupaten Jombang, tahun akademik 2017/2018. Subyek penelitian pada setiap uji coba memiliki perbedaan dalam hal jumlah siswa yang diikutsertakan dalam implementasi kegiatan pembelajaran. Pada uji coba pertama, penelitian dilakukan pada kelas kecil yang berjumlah enam siswa, sedangkan uji coba kedua dilakukan pada dua kelas replikasi yang berjumlah 29 siswa.

Model pengembangan LKS saintifik saintifik berbasis keterampilan berpikir kritis untuk siswa kelas V SDN Brodot I di Kabupaten Jombang I pada penelitian ini didasarkan pada model pengembangan 4-D (Thiagarajan, 1974). Model pengembangan LKS Saintifik berbasis berfikir kritis ini terdiri atas empat tahap, yaitu tahap pendefinisian (define), tahap perancangan (design), tahap pengembangan (develop) dan tahap penyebaran (disseminate).

Pada penelitian ini model 4D direduksi menjadi model 3D. Tahap pendefinisian merupakan langkah awal dari pengembangan LKS saintifik berbasis ketrampilan berfikir kritis siswa. Tahap ini bertujuan untuk menetapkan masalah-masalah yang dihadapi dalam kegiatan pembelajaran.. Pada tahap ini dilakukan beberapa analisis yang meliputi analisis kebutuhan, analisis siswa, analisis tugas, analisis konsep dan perumusan indikator/tujuan pembelajaran. Tahap perancangan bertujuan untuk menyusun LKS saintifik berbasis ketrampilan berfikir kritis yang akan diimplementasikan dalam kegiatan pembelajaran. Tahap ini meliputi penyusunan instrumen validasi, desain awal perangkat pembelajaran dan validasi pakar. Pada tahap pengembangan, uji coba pengembangan LKS saintifik berbasis ketrampilan berfikir 
kritis dilaksanakan untuk menganalisis dan merevisi LKS saintifik berbasis keterampilan berfikir kritis yang telah dikembangkan sehingga dapat memberikan hasil yang optimal. LKS saintifik berbasis ketrampilan berfikir kritis yang telah dikembangkan akan diujicobakan dalam kegiatan pembelajaran menggunakan desain penelitian one group pretest-posttest design.

Keterangan:

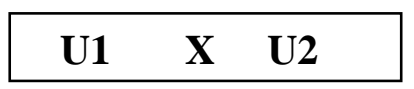

$\mathrm{U} 1$ = Pre-test; untuk mengetahui keterampilan berpikir kritis sebelum perlakuan

$\mathrm{U} 2$ = Post-test untuk mengetahui keterampilan berpikir kritis sesudah perlakuan.

$\mathrm{X}=$ Perlakuan; implementasi LKS saintifik berbasis keterampilan berpikir kritis

Dalam penelitian ini, peneliti menggunakan empat teknik pengumpulan data yaitu validasi LKS berbasis saintifik yaitu observasi, tes, dan angket. Validasi LKS berbasis saintifik untuk melatihkan ketrampilan berfikir kritis digunakan untuk mengetahui keterbacaan LKS berbasis saintifik yang telah dikembangkan oleh peneliti. Observasi digunakan untuk memperoleh data penelitian tentang keefektifan LKS berbasis saintifik dalam pembelajaran, aktivitas siswa, dan kendala-kendala selama kegiatan pembelajaran. Tes digunakan untuk memperoleh data penelitian tentang ketrampilan berpikir kritis yang dilatihkan kepada siswa. Angket digunakan untuk memperoleh data tentang respon siswa terhadap pembelajaran.

Data yang diperoleh akan dianalisis sesuai dengan karakteristik data. Teknik analisis dalam penelitian pengembangan perangkat pembelajaran ini didasarkan pada tiga aspek, yaitu aspek validitas dan aspek efektifitas.

Analisis validitas perangkat pembelajaran merupakan kegiatan penilaian yang dilakukan oleh para pakar terhadap perangkat pembelajaran yang dikembangkan. Validasi perangkat pembelajaran dilakukan sebelum implementasi kegiatan pembelajaran. Validasi perangkat pembelajaran pada penelitian ini meliputi komponen konstruk dan konten, serta keterbacaan perangkat pembelajaran. Penilaian dilakukan sesuai dengan rubrik pada setiap lembar validasi dan didasarkan pada rata-rata skor dari setiap komponen perangkat pembelajaran yang dinilai oleh validator. Skala penilaian yang diberikan validator terdiri atas beberapa kriteria, yaitu sangat baik (skala 4). baik (skala 3), kurang baik (skala 2) dan tidak baik (skala 1). Dari hasil validasi, perangkat pembelajaran dapat dikategorikan (1) dapat digunakan tanpa revisi, (2) dapat digunakan dengan sedikit revisi, (3) dapat digunakan dengan banyak revisi dan (4) belum dapat digunakan dan memerlukan konsultasi. Data hasil penilaian dianalisis secara deskriptif kualitatif. Skor rerata penilaian dari validator diinterpretasikan berdasarkan kategori penilaian tingkat validitas perangkat pembelajaran.

Analisis keterbacaan perangkat pembelajaran digunakan untuk mengukur tingkat keterbacaan BAM dan LKM berdasarkan persentase keterbacaan menggunakan cloze 
procedure. Cloze procedure dilakukan dengan pengisian kata-kata tertentu yang dihilangkan secara sistematis dalam kalimat.

Analisis keterampilan berpikir kritis didasarkan pada data hasil pre-test dan posttest, dilakukan analisis tes keterampilan berpikir kritis menggunakan analisis n-gain. Analisis n-gain untuk kemampuan pemecahan masalah didasarkan pada rubrik penilaian keterampilan berpikir kritis yang diadaptasi dari The Facione and Facione Holistic Scoring Rubric (Pierce, 2009). Gain menunjukkan perbedaan penguasaan kemampuan pemecahan masalah mahasiswa sebelum dan setelah diberikan perlakuan. Gain skor ternominalisasi menunjukkan tingkat ke-efektifan perlakuan daripada perolehan skor atau post-test. N-gain dirumuskan oleh Hake (1999).

\section{HASIL DAN PEMBAHASAN}

Penelitian pengembangan atau Research and Development (R\&D) ini terkait dengan implementasi pengembangan Lembar Kerja Siswa (LKS) saintifik berbasis keterampilan berpikir kritis terhadap siswa kelas V di SD Negeri Brodot I, Kabupaten Jombang. Pengembangan LKS saintifik berbasis keterampilan berpikir kritis mengukur kelayakan perangkat pembelajaran pada dua kriteria, yaitu kriteria validitas, yang ditunjukkan dari tingkat keterbacaan LKS saintifik, dan kriteria ke-efektifan, yang ditunjukkan dari keterampilan berpikir kritis siswa setelah implementasi LKS saintifik dalam kegiatan pembelajaran.

Validitas perangkat pembelajaran pada penelitian ini dilihat dari tingkat keterbacaan LKS saintifik. Keterbacaan LKS saintifik merupakan salah satu faktor yang menentukan ketercapaian indikator atau tujuan pembelajaran yang telah dirancang oleh peneliti sebelum implementasi pengembangan LKS saintifik oleh guru dalam kegiatan pembelajaran.

Pada penelitian ini dilakukan uji rumpang (cloze procedure) untuk melihat tingkat keterbacaan LKS saintifik. Hasil uji keterbacaan LKS saintifik menunjukkan tingkat keterbacaan tinggi sebesar 95,38\% yang berarti bahwa LKS saintifik yang dikembangkan pada penelitian ini dapat dibaca dan dipahami dengan baik oleh siswa (McKamey, 2006). Tingkat keterbacaan tinggi pada penelitian ini didukung dari hasil validasi LKS saintifik pada tiga aspek atau komponen penilaian, yaitu komponen format penyajian, komponen bahasa dan komponen isi. Hasil validasi pada ketiga komponen penilaian menunjukkan persentase reliabilitas masing-masing sebesar 93,72\%, 97,58\% dan $94,73 \%$.

Susunan kosa kata atau ejaan pada LKS saintifik disesuaikan dengan tingkat kognitif siswa kelas V yang, menurut teori Piaget (Nur, 2014), berada pada tahap operasional konkret.Kemampuan kognitif siswa pada tahap tersebut hanya dapat menghubungkan konsep-konsep IPA pada situasi atau benda konkret sehingga tata bahasa yang disajikan pada LKS saintifik merupakan masalah autentik yang umumnya ditemui siswa dalam kehidupan sehari-hari.

Kriteria ke-efektifan adalah tingkat keterterapan LKS saintifik yang dikembangkan pada penelitian ini setelah kegiatan pembelajaran terhadap keterampilan berpikir kritis siswa kelas V di SD Negeri Brodot I, Kabupaten Jombang. Hasil tes 
keterampilan berpikir kritis siswa pada setiap kelas replikasi dianalisis berdasarkan nilai pre-test, post-test dan pemerolehan $n$-gain.

Pre-test dan post-test didasarkan pada indikator keterampilan berpikir kritis, yaitu pendefinisian masalah, perumusan hipotesis, perumusan variabel percobaan, analisis data dan perumusan kesimpulan. Hasil nilai pre-test dan post-testdari siswa kelas V SD Negeri Brodot I pada kelas replikasi I dan II masing-masing dapat dilihat pada Tabel 1 dan Tabel 2.

Tabel 1. Hasil nilai pre-test dan post-test pada kelas replikasi I

\begin{tabular}{|c|c|c|c|c|}
\hline \multirow{2}{*}{$\begin{array}{c}\text { Indikator Keterampilan } \\
\text { Berpikir Kritis }\end{array}$} & \multicolumn{2}{|c|}{ Rata-rata Nilai } & \multirow[t]{2}{*}{ N-Gain } & \multirow{2}{*}{$\begin{array}{l}\text { Kategori } N- \\
\text { Gain }\end{array}$} \\
\hline & Pre-Test & Post-Test & & \\
\hline Pendefinisian Masalah & 39,69 & 81,56 & 0,69 & Sedang \\
\hline Perumusan Hipotesis & 36,25 & 78,75 & 0,67 & Sedang \\
\hline Perumusan Variabel Percobaan & 34,06 & 80,63 & 0,71 & Tinggi \\
\hline Analisis Data & 40,94 & 81,25 & 0,68 & Sedang \\
\hline Perumusan Kesimpulan & 40,63 & 79,06 & 0,65 & Sedang \\
\hline
\end{tabular}

Tabel 2. Hasil nilai pre-test dan post-testpada kelas replikasi II

\begin{tabular}{|c|c|c|c|c|}
\hline \multirow{2}{*}{$\begin{array}{c}\text { Indikator Keterampilan } \\
\text { Berpikir Kritis }\end{array}$} & \multicolumn{2}{|c|}{ Rata-rata Nilai } & \multirow[t]{2}{*}{ N-Gain } & \multirow{2}{*}{$\begin{array}{l}\text { Kategori } N- \\
\text { Gain }\end{array}$} \\
\hline & Pre-Test & Post-Test & & \\
\hline Pendefinisian Masalah & 23,58 & 76,42 & 0,71 & Tinggi \\
\hline Perumusan Hipotesis & 20,17 & 76,70 & 0,71 & Tinggi \\
\hline Perumusan Variabel Percobaan & 23,01 & 75,00 & 0,70 & Tinggi \\
\hline Analisis Data & 21,88 & 79,26 & 0,73 & Tinggi \\
\hline Perumusan Kesimpulan & 21,59 & 76,99 & 0,71 & Tinggi \\
\hline
\end{tabular}

Tabel 1 dan 2 dapat ditunjukkan bahwa pada kelas replikasi I didapatkan rata-rata $n$-gain berkategori tinggi yang ditunjukkan dengan nilai $n$-gainsebesar 0,68 dengan peningkatan rata-rata $n$-gain pada kelas replikasi II sebesar 0,71 . Indikator keterampilan berpikir kritis yang dominan pada kelas replikasi I adalah indikator perumusan variabel percobaan sebesar 0,71 , sedangkan pada kelas replikasi II n-gain tertinggi diperoleh indikator analisis data dengan $n$-gain 0,73 .

Pada penelitian ini keterlaksanaan kegiatan pembelajaran pada setiap kelas replikasi dapat dikategorikan baik dengan reliabilitas $83 \%$ untuk kelas replikasi I dan 93\% untuk kelas replikasi II. Tingkat reliabilitas kegiatan pembelajaran pada setiap kelas replikasi tidak terlepas dari peran guru dalam memberikan bantuan (scaffolding) kepada siswa.

Pemerolehan nilai n-gain merepresentasikan hasil observasi dari kegiatan pembelajaran pada dua kelas replikasi memperlihatkan kemampuan guru dalam memotivasi siswa untuk mengikuti kegiatan pembelajaran dengan baik. Selain itu, guru juga dapat mengkomunikasikan tujuan pembelajaran terutama pada aspek apersepsi dan penyampaian materi prasyarat. Pada kegiatan inti, pada setiap kelas replikasi guru memberikan tanggung jawab kepada siswa untuk melakukan praktikum secara mandiri dengan memberikan bantuan (scaffolding/mediated learning) kepada siswa sebatas pada pendefinisian masalah, sementara kegiatan pembelajaran untuk merumuskan hipotesis sampai dengan perumusan kesimpulan dilakukan secara mandiri. Guru dapat 
memberikan bantuan selama tahap awal pembelajaran dan secara bertahap mengurangi bantuan tersebut untuk memberikan kesempatan kepada siswa mengambil alih tangung jawab untuk menyelesaikan masalah (Nur, 2008). Brickman (2009) menyatakan bahwa kegiatan pembelajaran yang mengimplementasikan perangkat pembelajaran saintifik dapat melatihkan kemampuan berpikir kritis sehingga siswa dapat mengkonstruksi pengetahuannya secara mandiri. Ashiq Hussain, dkk. (2011) juga berpendapat bahwa implementasi perangkat pembelajaran saintifik dalam kegiatan pembelajaran dapat meningkatkan hasil belajar siswa dengan mengaplikasikan konsep-konsep IPA dalam kehidupan sehari-hari. Kegiatan pembelajaran untuk mengaplikasikan konsep IPA ini memerlukan peran serta guru dalam penelitian ini untuk mempersiapkan alat dan bahan percobaan serta melakukan pembimbingan secara langsung dengan menunjukkan alat dan bahan percobaan yang akan digunakan beserta tata cara penggunaannya. Tujuan dari kegiatan peran serta guru ini adalah membimbing siswa kearah berpikir yang sesuai dengan prosedur percobaan. Hal ini memiliki banyak manfaat yaitu perhatian siswa dapat dipusatkan pada hal-hal yang dianggap penting, dapat mendukung efisiensi waktu kegiatan pembelajaran, dapat mengurangi kesalahan yang dilakukan siswa selama kegiatan praktikum, guru dapat memberikan scaffolding kepada siswa selama kegiatan percobaan dan permasalahan yang menimbulkan pertanyaan atau keraguan pada benak siswa dapat diatasi selama kegiatan pembelajaran (Rusyan, 1994).

\section{KESIMPULAN}

Berdasarkan temuan-temuan penelitian yang telah dipaparkan dapat disimpulkan bahwa Lembar Kerja Siswa (LKS) yang dikembangkan pada penelitian ini memenuhi kriteria validitas dan ke-efektifan LKS sehingga layak untuk diimplementasikan dalam kegiatan pembelajaran. Validitas LKS dapat dilihat dari validitas keterbacaan. Keefektifan perangkat pembelajaran meliputi kemampuan saintifik dan keterampilan berpikir kritis siswa setelah implementasi kegiatan pembelajaran menggunakan LKS saintifik yang telah dikembangkan pada penelitian ini.

\section{DAFTAR PUSTAKA}

Hosnan, M. (2014). Pendekatan Saintifik dan Kontekstual dalam Pembelajaran Abad 21. Bogor: Ghalia Indonesia.

Kemendikbud, (2013).PendekatanScientific (Ilmiah) dalamPembelajaran. Jakarta: Pusbangprodik.

Kemendikbud, (2013).PengembanganKurikulum 2013.

PaparanMendikbuddalamSosialisasiKurikulum. Jakarta: Kemendikbud.

Sani, R. A. (2014). Pembelajaran Saintifik untuk Implementasi Kurikulum 2013. Jakarta: PT Bumi Aksara.

Sugiyono.(2008). MetodePenelitianKuantitatif, Kualitatifdan R\&D, Bandung; Alfabet Sukmadinata Nana Syaodih (2007), MetodePenelitianPendidikan, Bandung; Remaja Rosda Karya. 